was entitled to consider that the prohibition of the possession for use of DMT was necessary in a democratic society for the protection of health, considering its known effects as described above.'

Het verbieden van bepaalde drugs lijkt dus gewoon een legitieme inbreuk op de vrijheid van godsdienst te kunnen maken. De Hoge Raad leidde hieruit af dat voor de beoordeling van de noodzakelijkheid van de inbreuk in een democratische samenleving niet steeds een afweging per situatie is vereist, maar een algemene toetsing volstaat. Het oordeel van het hof dat de toepassing van de betreffende Opiumwetbepalingen en daarmee de beperking van het recht op vrijheid van godsdienst van de verdachte in gevallen als het onderhavige in een democratische samenleving noodzakelijk is ter bescherming van de volksgezondheid, was dan ook niet onbegrijpelijk.

\section{NTS 2020/21}

\section{HR 1 oktober 2019, 17/00380, ECLI:NL:HR:}

2019:1454

Oplichting (meermalen gepleegd) door via 'onzinverhalen' tegenover kmetsbare oudere dame andere personen uit haar kennissenkring te bemegen tot afgeven van geldbedragen t.g.v. verdachte, art. $326 \mathrm{Sr}$

\section{Aantekening redactie}

Voor oplichting ex artikel 326 lid $1 \mathrm{Sr}$ is vereist dat iemand door een oplichtingsmiddel wordt 'bewogen' tot in die bepaling bedoelde handelingen. Niet vereist is dat het oplichtingsmiddel rechtstreeks wordt aangewend jegens degene die wordt bewogen tot desbetreffende handelingen. Oplichting kan ook geschieden door tegenover een (niet-strafbare) tussenpersoon het oplichtingsmiddel an te wenden, mits verdachte daarbij heeft gehandeld met het in artikel $326 \mathrm{Sr}$ bedoelde oogmerk. ${ }^{18}$ Het hof heeft de verdachte wegens 'oplichting, meermalen gepleegd' veroordeeld tot een gevangenisstraf. Het middel bevatte de klacht dat het oordeel van het hof dat de verdachte de in de betreffende personen heeft 'bewogen' tot afgifte van geldbedragen op de wijze zoals bewezen is verklaard, getuigde van een onjuiste rechtsopvatting, althans onbegrijpelijk is dan wel onvoldoende met redenen was omkleed.
Wat was er gebeurd? Verdachte heeft op zeer geraffineerde wijze misbruik gemaakt van een oudere dame, die het goed met hem voorhad. Tegenover haar deed hij zich op allerlei manieren voor als slachtoffer van omstandigheden, dat op korte termijn weer over geld zou kunnen beschikken. Zo heeft verdachte erkend dat hij tegen de oude dame verschillende onzinverhalen heeft verteld. Hij vertelde onder meer dat hij werkzaam was bij de Europese Unie dan wel de NAVO, voor die baan veel moest reizen en hij niet over zijn geld kon beschikken omdat zijn rekening was geblokkeerd dan wel vanwege een registratie bij het BKR. Voorts heeft hij diverse berichten, zoals e-mailberichten van zogenaamde werkgevers en sms-berichten, vals opgemaakt om zijn onzinverhalen kracht bij te zetten. De oude dame had toegang tot deze stukken, en gebruikte de informatie als ze geld vroeg aan anderen ten behoeve van verdachte. De aangevers zijn aanvankelijk steeds benaderd door de oude dame. Zij heeft, nadat haar eigen financiële mogelijkheden ten behoeve van verdachte waren uitgeput, mensen uit haar kennissenkring gevraagd om verdachte financieel te ondersteunen. Op die manier kreeg verdachte toegang tot mensen die hij anders wellicht nooit succesvol had kunnen benaderen: ouderen, die gelet op de (soms al decennia bestaande) vriendschap met de oude dame vol vertrouwen waren. De oude dame vertelde de onzinverhalen die verdachte haar vertelde door aan haar kennissenkring. Vast staat dat al die over verdachte vertelde verhalen 'verzinsels' van verdachte betroffen. Aangevers zijn vervolgens overgegaan tot het geven van geld aan de oude dame ten behoeve van verdachte. De oude dame leidde dit geld telkens door naar verdachte. In totaal zijn er tonnen bij verdachte terechtgekomen en door hem uitgegeven. Toen aangevers, tevergeefs, probeerden hun geld terug te krijgen heeft verdachte ze eindeloos aan het lijntje gehouden en tegen hen gelogen. Door de verdediging werd aangevoerd dat nu er op één situatie na nooit ontmoetingen hebben plaatsgevonden tussen verdachte en deze derden, die derden niet door de verdachte zijn opgelicht. Het hof oordeelde echter dat verdachte op zijn minst de aanmerkelijke kans had aanvaard dat door zijn handelen derden werden bewogen tot het afgeven van geld en dat daarom van oplichting kon worden gesproken. De vraag was dus of van oplichting ook sprake kan zijn als de oplichtingsmiddelen niet rechtstreeks worden aangewend jegens degene die een goed afgeeft, maar door tussenkomst van een derde. Uit eerdere rechtspraak van de Hoge Raad kon reeds worden opgemaakt dat 'indirecte oplichting' wel degelijk mogelijk is, ${ }^{19}$ mits het opzet van de verdachte erop is gericht om van het (niet direct benaderde) slachtoffer de afgifte te verkrijgen. Dat opzet bestaat uit 'oogmerk', wat uiteraard betekent dat voorwaardelijk opzet niet volstaat. $\mathrm{Nu}$ de oude dame in deze zaak niet als medepleger werd aangemerkt en het hof op voorwaardelijk opzet geënte bewoordingen bezigde, was het opzet nog wel een issue. 
De Hoge Raad oordeelde dat met uitzondering van het ene slachtoffer dat wel persoonlijk door de verdachte was benaderd, het oplichten van de slachtoffers door de verdachte niet uit de bewijsvoering kon worden afgeleid:

'Blijkens de bewijsvoering heeft het Hof onder meer vastgesteld dat de verdachte zich mede met behulp van 'onzinverhalen' tegenover een oudere dame, [betrokkene 1], heeft voorgedaan als een slachtoffer van omstandigheden dat op korte termijn weer over geld zou kunnen beschikken. Nadat haar eigen financiële mogelijkheden waren uitgeput, heeft [betrokkene 1] die verzinsels doorverteld aan diverse personen uit haar kennissenkring en deze gevraagd om de verdachte financieel te ondersteunen. Die personen hebben vervolgens geld gegeven aan [betrokkene 1] ten behoeve van de verdachte. Uit de bewijsvoering volgt voorts dat, op aangever [benadeelde 2] na, tegen wie de verdachte zelf heeft gelogen teneinde deze te bewegen tot afgifte van geldbedragen, de aangevers aanvankelijk steeds door [betrokkene 1] zijn benaderd om geldbedragen af te geven.

De bewezenverklaringen, voor zover inhoudende dat de verdachte zich telkens schuldig heeft gemaakt aan oplichting van [benadeelde 1], [benadeelde 3], [benadeelde 4], [benadeelde 5], [benadeelde 6] , [benadeelde 7], [benadeelde 8], [benadeelde 10] en [benadeelde 9], kan niet zonder meer worden afgeleid uit de door het Hof gehanteerde bewijsvoering. De bestreden uitspraak is in zoverre, mede in het licht van hetgeen hiervoor onder 2.3 is vooropgesteld, niet naar de eis der wet met redenen omkleed.

Daarbij wordt in aanmerking genomen dat het Hof omtrent het oogmerk van de verdachte om zich door de in de bewezenverklaringen genoemde oplichtingsmiddelen wederrechtelijk te bevoordelen niet meer heeft overwogen dan dat de verdachte 'op zijn minst de aanmerkelijke kans [heeft] aanvaard dat door zijn handelen derden werden bewogen tot het afgeven van geld' en dat het Hof onvoldoende feiten en omstandigheden heeft vastgesteld waaruit kan worden afgeleid dat het de verdachte is geweest die rechtstreeks of indirect door de in de bewezenverklaringen vermelde oplichtingshandelingen de daarin genoemde personen heeft bewogen tot afgifte van geldbedragen. Het middel is in zoverre terecht voorgesteld.'
NTS 2020/22

HR 1 oktober 2019, 18/01412, ECLI:NL:HR:

2019:1458

Medeplegen diefstal met gemeld (art. 312.2.2 Sr), meermalen gepleegd, medeplegen poging tot afpersing (art. 317 jo. 312.2.2 Sr) en medeplegen oplichting (art. 326 $\mathrm{Sr}$ ). Kon Hof gelet op art. $63 \mathrm{Sr}$ toekomen aan strafoplegging, nu verdachte kort daarvoor in België reeds was veroordeeld tot levenslange gevangenisstraf t.z.v. in dezelfde periode gepleegde samenhangende feiten?

\section{Aantekening redactie}

De verdachte is door het hof ter zake van (i) 'diefstal, voorafgegaan en vergezeld van geweld en bedreiging met geweld tegen personen, gepleegd met het oogmerk om die diefstal voor te bereiden en gemakkelijk te maken, terwijl het feit wordt gepleegd door twee of meer verenigde personen', (ii) 'poging tot afpersing, terwijl het feit wordt gepleegd door twee of meer verenigde personen', (iii) 'diefstal, voorafgegaan en vergezeld van geweld en bedreiging met geweld tegen personen, gepleegd met het oogmerk om die diefstal voor te bereiden en gemakkelijk te maken, terwijl het feit wordt gepleegd door twee of meer verenigde personen' en (iv) 'medeplegen van oplichting' veroordeeld tot een gevangenisstraf van acht jaren. In het kader van de persoonlijke omstandigheden van de verdachte nam het hof mee in zijn beoordeling dat de verdachte in België recentelijk is veroordeeld tot een levenslange gevangenisstraf ter zake van onder meer een roofmoord. Anders dan door de verdediging betoogd, bracht dit volgens het hof niet met zich mee dat voor strafoplegging in de voorliggende zaak thans geen plaats meer was. Het middel klaagde dat het hof het gevoerde verweer dat het hof niet meer aan strafoplegging kon toekomen nu de verdachte reeds in België is veroordeeld tot een levenslange gevangenisstraf ten onrechte, althans op ontoereikende gronden heeft verworpen. In ECLI:NL:HR:2018:306 overwoog de Hoge Raad reeds dat het de rechter vrijstaat een eerdere, in een andere lidstaat van de Europese Unie uitgesproken veroordeling bij de straftoemeting in aanmerking te nemen. Echter, indien bij een buitenlandse rechterlijke beslissing aan de verdachte straf is opgelegd, levert die strafoplegging niet een veroordeling op als bedoeld in 